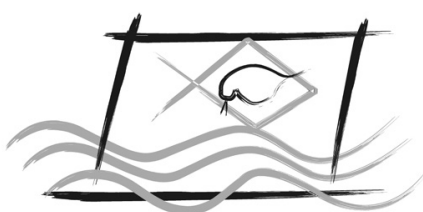

ECOTOX - BRASIL

\title{
Branchiura sowerbyi reared in two sediments for ecotoxicological bioassays
}

\author{
Lobo, H. \& EspíndolA, E.L.G. \\ Núcleo de Ecotoxicologia e Ecologia Aplicada, Programa de Pós-Graduação em Ciências da Engenharia Ambiental, EESC/USP. Avenida \\ Trabalhador Sãocarlense, 400. Cep. 13564-590, São Carlos, SP. Brasil.
}

(Received August 24, 2015; Accept April 11, 2016)

\begin{abstract}
The present work compared the survival, growth, and reproduction of Branchiura sowerbyi reared in natural sediment and in artificial tropical sediment (composed of sand, clay, and coconut fibers). The artificial tropical sediment, in the tested composition, appeared not to be suitable for conducting bioassays with this species, since the results showed a high mortality of the juveniles and low reproduction of adults as compared to those observed for the natural sediment.
\end{abstract}

Key Words: peat extract, coconut fiber, oligochaete, artificial sediment.

\section{INTRODUCTION}

For conducting bioassays, rearing a test species in a laboratory is recommended above field-collection on animals (ASTM, 2005). Aquatic oligochaetes require sediments that are able to guarantee an adequate level of survival, growth and reproduction of the test-species. The international protocols for sediment toxicity testing with oligochaetes have recommended the use of natural sediments from places free of contamination, or formulated (artificial) sediments constructed using pre-defined proportions of sand, silt/clay and organic material (Environment Canada, 1995; ASTM, 2005; OECD, 2008).

Some authors, such as Kembel et al. (1999), Arrate et al. (2004), and Slootweg et al. (2010), successfully conducted bioassays with limnic oligochaetes using artificial sediments. For constructing the sediment, they used sand, clay and peat; ingredients all easily obtained in temperate climates. However, for culturing and testing with tropical species, it may be necessary to adapt that composition, because peat may be logistically and financially out of reach in tropical countries. As an alternative, Garcia (2004) replaced peat by coconut fiber powder (Coco nucifera $\mathrm{L}$.) in some toxicity tests using Eisenia foetida (Savigny), a terrestrial oligochaete. The two compositions (peat and coconut fiber powder) yielded similar results with respect to growth, reproduction, and survival, leading to the successful adoption of this substitute substrate by other authors (Buch et al., 2011; Nunes \& Espíndola, 2012). Yet there are still no records of aquatic bioassay studies in tropical regions that have used coconut fiber powder to formulate sediments.

With the goal of increasing the use of artificial sediments for toxicity bioassays in tropical regions, we sought to compare rates of survival, growth, and reproduction of the oligochaete Branchiura sowerbyi Beddard, kept in natural sediment (NS) and in artificial tropical sediment (ATS), using coconut fiber powder as a substitute for peat. This species was chosen because it is a tropical species that can be cultured along a range of sediment types (Aston \& Milner, 1981; Casellato et al., 1992; Marchese \& Brinkhurst, 1996; Ducrot et al., 2007; Nascimento \& Alves, 2008; Lobo \& Alves, 2011), and has been used as test species in ecotoxicological bioassays (Lobo \& Espíndola, 2014).

\section{MATERIAL AND METHODS}

The NS was collected in Córrego Perdizes (Brotas, São Paulo, Brazil: 199470.46X; 7543013.73Y; 23K). After collection, the sediment was sieved (mesh sieve $0.5 \mathrm{~mm}$ ) in order to remove undesired organisms, and kept at $4^{\circ} \mathrm{C}$ for up 
to 30 days. Córrego Perdizes is classified as oligo-mesotrophic (Sanchez, 2012), and its sediment has been used as a control sediment in other (non-published) studies, as well as a substrate to rear $B$. sowerbyi, at the Núcleo de Ecotoxicologia e Ecologia Aplicada (NEEA) of the Universidade de São Paulo (São Carlos, Brazil).

The ATS was prepared in accordance with the instructions of the protocol EPS 1/RM/30 of Environment Canada (1995), using sand (Brazilian Standard Sand, NBR 7214/82), white clay (kaolin U.S.P. 26, Synth ${ }^{\circledR}$ ) and coconut fiber powder (Golden Mix T-80; Amafibra ${ }^{\circledR}$ ), instead of peat extract as organic matter (see Report EPS 1/RM/30 of Environment Canada, 1995 for more details). The ATS was stored at $4^{\circ} \mathrm{C}$ until test set-up (storage time did not exceed 7 days). In Table 1 , the compositions of the two sediments are displayed. The NS are classified as medium to coarse sand and the ATS are muddy sands. We aimed to maintain the characteristics of the artificial sediment recommended by Environment Canada (1995), formulating a sediment with an organic matter content between 2 and $10 \%$. The percentage of phosphorus was also different between the sediments since coconut fiber has a considerable phosphorus content (Abad et al., 2002).

The bioassays followed the protocol developed by Lobo \& Alves (2011). In the bioassays, we used B. sowerbyi originating from the cultures kept at NEEA. Two bioassays were run to compare the sediments: one with adult organisms (10 weeks old), for 28 days, and another with juveniles (one week old) for 14 days. In the first test, survival, reproduction, and growth rates were assessed as endpoints, while in the second only survival was considered. Sixty healthy organisms (with normal movement and the adults with the presence of egg's in the ovisac) were selected for each bioassay (30 individuals per sediment treatment). Six replicates, containing five individuals per $250 \mathrm{~mL}$ beaker each, were prepared for the respective sediments. Each beaker was filled with $100 \mathrm{~mL}$ sediment, $100 \mathrm{~mL}$ reconstituted water, and $0.21 \mathrm{~g}$ of Tetramin ${ }^{\circledR}$ as food supplement (food was provided only at the beginning of the experiments). The beakers were kept at $25 \pm 1{ }^{\circ} \mathrm{C}$, under moderate aeration, with photoperiod of $12 \mathrm{~L}: 12 \mathrm{D}$, for 28 days. The water level was adjusted weekly in order to compensate for the loss of water due to evaporation. At the end of the 28 days, the sediments from the beakers were washed in a $0.25 \mathrm{~mm}$ mesh and analyzed on a light box to verify the

Table 1 - Characteristics of Natural Sediment (NS) and Artificial Tropical Sediment (ATS) used in bioassays with Branchiura sowerbyi (all values refer to dry weight).

\begin{tabular}{lcc}
\hline Composition & NS $^{\mathrm{a}}$ & ATS \\
\hline Grain size & & \\
Coarse sand $(0,5-0,25 \mathrm{~mm})$ & $46.28 \%$ & $0 \%$ \\
Medium sand $(0,25-0,105 \mathrm{~mm})$ & $48.43 \%$ & $75 \%$ \\
Fine sand $(0,105-0,053 \mathrm{~mm})$ & $4.51 \%$ & $0 \%$ \\
Silte and clay $(<0,053 \mathrm{~mm})$ & $0.78 \%$ & $21 \%$ \\
Organic Matter (LOI $)$ & $0.75 \%$ & $4 \%$ \\
Total Nitrogen & $0.09 \%$ & $0.09 \%$ \\
Total Phosphorous & $0.204 \mu \mathrm{g} \mathrm{g}^{-1}$ & $0.657 \mu \mathrm{g} \mathrm{g}^{-1}$ \\
\hline
\end{tabular}

number of surviving adults, cocoons, eggs and juveniles. To determine the biomass, adults were kept for $4 \mathrm{~h}$ in Petri dishes containing only reconstituted water, to empty their intestinal content (feces were removed by pipette to avoid coprophagy), and then weighed on an analytic scale with a precision of $0.1 \mathrm{mg}$. The average daily growth rate $\left(\mathrm{G}_{\mathrm{w}} \%\right)$ was calculated according to Reynoldson (1987): $\mathrm{G}_{\mathrm{w}} \%=\left(\operatorname{Ln} W_{2}-\operatorname{Ln} W_{1}\right) \mathrm{x}$ $100 t^{-1}$, where $W_{1}=$ initial biomass (mg); $W_{2}=$ final biomass (mg); and $t=$ time in days.

The pH (Micronal B374, São Paulo, Brazil), electrical conductivity (Thermo Orion M145, Beverly, USA), concentration of dissolved oxygen (Yellow Springs YSI-55, Ohio, USA) and total ammonia concentrations (spectrophotometry method, APHA 1995) were measured every other day. All the equipment used were calibrated according to the manufacturer's instructions. Statistical analyses were undertaken with the free software R (R Core Team, 2013), using the Student $t$ test $(p=0.05)$ to compare the two treatments.

\section{RESULTS}

Physical and chemical parameters of the water were very similar between the treatments $(\mathrm{pH}=7.79 \pm 0.26$ and $7.79 \pm 0.10 ; \mathrm{OD}=6.94 \pm 0.27$ and $6.64 \pm 0.31 \mathrm{mg} \mathrm{L}^{-1}$; ammonia $=0.75 \pm 0.10$ and $0.84 \pm 0.09 \mathrm{mg} \mathrm{L}^{-1}$, for NS and ATS respectively) with the exception of conductivity (NS: $254.19 \pm 34.07$ and ATS: $404.14 \pm 34.70 \mu \mathrm{S} \mathrm{cm}^{-1}, \mathrm{p}<0.05$ ). All parameters remained within the tolerance limits of $B$. sowerbyi (Chapman et al., 1982) and in accordance with the standards for chronic bioassays established for oligochaetes (ASTM, 2005).

At the end of the 28-day test period, $100 \%$ and $70 \%$ survival rates were recorded for NS and ATS, respectively. The organisms kept in NS presented increases in their biomasses, while those kept in ATS showed biomass reduction, resulting in a significant difference between the final weights, demonstrated by the $\mathrm{Gw} \%$ (Table 2). Only the average number of eggs per cocoon and the initial weights did not differ significantly between organisms exposed to NS and ATS.

In the second experiment, the survival rate after 14 days of juveniles kept in NS was $90.74 \%$, contrasting with only $3.7 \%$ of those kept in ATS.

Table 2 - Biological parameters observed in bioassays with adult Branchiura sowerbyi, kept in Natural Sediment (NS) and Artificial Tropical Sediment (ATS).

\begin{tabular}{lccc}
\hline Biological Parameters & NS & ATS & Statistics \\
\hline Survival (\%) & $100 \pm 0.00$ & $70 \pm 11.55$ & $*$ \\
Average growth rate (\%) & $0.35 \pm 0.24$ & $-0.44 \pm 0.24$ & $* *$ \\
Initial average weight $(\mathrm{mg})$ & $23.79 \pm 0.56$ & $25.56 \pm 1.97$ & \\
Final average weight $(\mathrm{mg})$ & $26.34 \pm 1.41$ & $21.43 \pm 1.68$ & $*$ \\
Average number of cocoons & $19.00 \pm 6.24$ & $2 \pm 0.001$ & $*$ \\
Average number of eggs per cocoon & $1.74 \pm 0.09$ & $1.33 \pm 0.29$ & \\
Average of cocoons per adult per day & $0.14 \pm 0.04$ & $0.02 \pm 0.001$ & $*$ \\
$*$ - $\mathrm{p}<0.05 ; * *-\mathrm{p}<0.001$. & & &
\end{tabular}




\section{DISCUSSION}

There are no records on the use of artificial sediments for the rearing of $B$. sowerbyi, however, although they have frequently been used in ecotoxicological tests with other benthic organisms (Kembel et al., 1999; Goedkoop \& Peterson, 2003; Slootweg et al., 2010).

For the organisms kept in NS, the $\mathrm{Gw} \%$ found for $B$. sowerbyi was very similar to that found for this species in other studies (values close to 0.5\%; Marchese \& Brinkhurst, 1996; Lobo \& Alves, 2011). Concerning individual fertility, Ducrot et al. (2007) and Lobo \& Alves (2011) recorded postures of 0.16 and 0.11 cocoons day ${ }^{-1}$, respectively, with an average of $2.2 \pm 0.4$ and $1.73 \pm 0.57$ eggs cocoon ${ }^{-1}$; values close to those found in the present study. These results, added to a survival rate of $100 \%$, demonstrate that the NS used can be considered suitable for rearing $B$. sowerbyi.

Concerning the results obtained for ATS, all endpoints analyzed were worse than observed for NS. Organism survival after 28 days was $70 \%$, which was lower than $90 \%$, i.e. the limit recommended by ASTM (2005) for T. tubifex tests.

Following Arrate et al. (2004), increased ammonia concentration originating from organic material decomposition and food supplements can cause negative side effects, including the death of adults. However, in the present work, the concentration of total ammonia was below $1 \mathrm{mg} \mathrm{L}^{-1}$, which is not considered toxic for many benthic invertebrates (Monda et al., 1995).

Despite the analyses of several parameters we conducted, it was not possible to determine the cause of the high mortality of the organisms in the artificial tropical sediment (ATS). In accordance with Garcia (2004), the coconut fiber powder used to formulate artificial soils does not cause negative side effects in terrestrial oligochaetes, but from our results it thus appears not to be a viable option for freshwater oligochaetes.

Due the higher concentration of organic matter in the ATS ( $4.00 \%$, against $0.75 \%$ in NS), we expected to find better fitness and reproduction for organisms in this treatment. One of our hypotesis for this opposite result is that the coconut fibers probably decompose less quickly than the peat extract, demanding a longer period of hydration and decomposition by bacteria. Garcia (2004) left the coconut fiber powder decompose for 30 days before use in the soils, a week more than in the present study, where the time of decomposition was 21 days (in accordance with Environment Canada, 1995). This longer period could provide greater food availability for the oligochaetes, once it will allow the establishment of a higher density of bacteria (primary food source for oligochaetes, Brinkhurst \& Chua, 1969; Wavre \& Brinkhurst, 1971) and consequently a higher degree of mineralization of the organic matter, with the breaking of the coconut fiber into simpler compounds that could be assimilated by the gut of the oligochaetes (subject for future studies). Rodriguez et al. (2001) observed a high content of vegetal fibers from peat components in fecal pallets of T. tubifex maintained in artificial sediment, suggesting that this fiber was neither digested nor assimilated by the oligochaetes.

Another hypothesis is that the coconut fiber may release some toxic substance during its decomposition. According to Rosa et al. (2001), the coconut fiber presents a high concentration of tannin, a toxic substance that could adversely affect aquatic organisms (Hedmark \& Scholz, 2008). Even with the wash process to obtain the fibers, reported by the manufacturer, the toxic substances could remain and reach lethal levels to the oligochaetes and/or to the bacteria, food source for B. sowerbyi. This hypothesis should be tested in future works.

From our results, we may conclude that the ATS, in the composition previously successfully used for terrestrial oligochaete tests, is not a viable option for tests with the aquatic oligochaete $B$. sowerbyi, given that it caused a high mortality rate in adults and juveniles when compared with the NS tested. However, new studies are necessary to assess why ATS affected the species during the bioassays and what alternative ATS could be used for aquatic organisms.

\section{ACKNOWLEDGEMENTS}

We thank the Brazilian National Council for Scientific and Technological Development (CNPq) for the scholarship of the first author (Process: 140771/2010-7), as well as the São Paulo Research Foundation (FAPESP) and the Brazilian Federal Agency for Support and Evaluation of Graduate Education (CAPES) for their funding. We also like to thank Dr. Michiel Daam (University of Aveiro, Portugal) for the textual contributions.

\section{REFERENCES}

ABAD, M., NOGUERA, P., PUCHADES, R., MAQUIEIRA, A. \& NOGUERA, V. 2002. Physico-chemical and chemical properties of some coconut coir dust for uses as a peat substitute for containerised ornamental plants. Bioresour. Technol., 82: 241245. http://dx.doi.org/10.1016/S0960-8524(01)00189-4

APHA (1995) Standard Methods for the Examination of Water and Wastewater. 19th edn. APHA, Washington DC, USA.

ARRATE, J.A., RODRIGUEZ, P. \& MARTINEZ-MADRID, M. 2004. Tubifex tubifex chronic toxicity test using artificial sediment: methodological issues. Limnetica, 23: 25-36

ASTM (American Society for Testing and Materials). 2005. Standard test method for measuring the toxicity of sediment-associated contaminants with freshwater invertebrates E1706-05. 117p.

ASTON, R.J. \& MILNER, A.G.P. 1981. Conditions required for the culture of Branchiura sowerbyi (Oligochaeta: Tubificidae) in activated sludge. Aquaculture, 26: 155-166. http://dx.doi. org/10.1016/0044-8486(81)90118-6

BUCH, A.C., BROWN, G.G., NIVA, C.C., SAUTTER, K.D. \& LOURENÇATO, L.F. 2011. Life cycle of Pontoscolex corethrurus (Müller, 1857) in tropical artificial soil. Pedobiologia, 54S: S19-S25. http://dx.doi.org/10.1016/j.pedobi.2011.07.007

BRINKHURST, R.O. \& CHUA, K.E. 1969. Preliminary investigation of the exploitation of some potential nutritional resources by three sympatric tubificid oligochaetes. J. Fish. Res. Board Can., 
26: 2659-2668.

CASELLATO, S.; AIELLO, R.; NEGRISOLO, P.A. \& SENO, M. 1992. Long-term experiment on Branchiura sowerbyi Beddard (Oligochaeta, Tubificidae) using sediment treated with LAS (Linear Alkylbenzene Sulphonate). Hydrobiologia, 232: 169173. http://dx.doi.org/10.1007/BF00017476

CHAPMAN, P.M., FARRELL, M.A. \& BRINKHURST, R.O. 1982. Relative tolerances of selected aquatic oligochaetes to individual pollutants and environmental factors. Aquat. Toxicol., 2: 47-67. http://dx.doi.org/10.1016/0166-445X(82)90006-6

DUCROT, V., PÉRY, A.R.R., QUÉAU, H., MONS, R., LAFONT, M. \& GARRIC, J. 2007. Rearing and estimation on lifecycle parameters of the tubificid worm Branchiura sowerbyi: Application to ecotoxicity testing. Sci. Total Environ., 384: 252263. http://dx.doi.org/10.1016/j.scitotenv.2007.06.010

ENVIRONMENT CANADA. 1995. Environmental Protection Series: Guidance document on measurement of toxicity test precision using control sediments spiked with a reference toxicant. EPS 1/RM/30.69p.

GARCIA, M. 2004. Effects of pesticides on soil fauna: development of ecotoxicological test methods for tropical regions. PhD Thesis. Universität Bonn. 291p.

GOEDKOOP, W. \& PETERSON, M. 2003. The fate, distribution, and toxicity of lindane in tests with Chironomus riparius: effects of bioturbation and sediment organic matter content. Environ. Toxicol. Chem., 22: 67-76. http://dx.doi.org/10.1002/ etc. 5620220109

HEDMARK, A. \& SCHOLZ, M. 2008. Review of environmental effects and treatment of runoff from storage and handling of wood. Bioresource Technol., 99: 5997-6009. http://dx.doi. org/10.1016/j.biortech.2007.12.042

KEMBEL, N.E., DWYER, F.J., INGERSOLL, C.G., DAWSON, T.D. \& NORBERG-KING, T.J. 1999. Tolerance of freshwater test organisms to formulated sediments for use as control materials in whole-sediment toxicity tests. Environ. Toxicol. Chem., 18: 222-230. http://dx.doi.org/10.1002/etc.5620180218

LOBO, H. \& ALVES, R.G. 2011. Reproductive cycle of Branchiura sowerbyi (Oligochaeta: Naididae: Tubificinae) cultivated under laboratory conditions. Zoologia, 28: 427-431. http://dx.doi. org/10.1590/S1984-46702011000400003

LOBO, H. \& ESPÍNDOLA, E.L.G. 2014. Branchiura sowerbyi (Oligochaeta: Naididae) as a test species in ecotoxicology bioassays: a review. Zoosymposia, 9: 59-69. http://dx.doi. org/10.11646/zoosymposia.9.1.11

MARCHESE, M.R. \& BRINKHURST, R.O. 1996. A comparison of two tubificid oligochaete species as candidates for sublethal bioassay tests relevant to subtropical and tropical regions.
Hydrobiologia, 334: 163-168. http://dx.doi.org/10.1007/978-94011-5452-9_19

MONDA, D.P., GALAT, D.L., FINGER, S.E. \& KAISER, M.S. 1995. Acute toxicity of ammonia (NH3-N) in sewage effluent to Chironomus riparius. II. Using a generalized linear model. Arch. Environ. Contam. Toxicol., 28: 385-390. http://dx.doi. org/10.1007/BF00213117

NASCIMENTO, H.L.S. \& ALVES, R.G. 2008. Cocoon production and hatching rates of Branchiura sowerbyi Beddard (Oligochaeta: Tubificidae). Rev. Bras. Zool., 25: 16-19. http:// dx.doi.org/10.1590/S0101-81752008000100003

NUNES, M.E.T. \& ESPÍNDOLA, E.L.G. 2012. Sensitivity of Eisenia andrei (Annelida, Oligochaeta) to a commercial formulated of abamectin in avoidance tests with artificial substrate and natural soil under tropical conditions. Ecotoxicology, 21: 1063-1071. http://dx.doi.org/10.1007/s10646-012-0859-6

OECD (Organization for Economic Cooperation and Development). 2008. Guideline 315: Guidelines for the testing of chemicals: bioaccumulation in sediment-dwelling benthic oligochaetes. $32 \mathrm{p}$.

R CORE TEAM. 2013. R: A language and environment for statistical computing. R Foundation for Statistical Computing. Vienna, Austria. ISBN: 3-900051-07-0. URL: http://www.R-project.org/.

REYNOLDSON, T.B. 1987. The role of environmental factors in the ecology of tubificid oligochaetes: an experimental study. Holarctic Ecol., 10: 241-248. http://dx.doi.org/10.1111/j.1600-0587.1987. tb00765.x

RODRIGUEZ, P., MARTINEZ-MADRID, M., ARRATE, J.A. \& NAVARRO, E. 2001. Selective feeding by the aquatic oligochaete Tubifex tubifex (Tubificidae, Clitellata). Hydrobiologia, 463: 133-140. http://dx.doi.org/10.1023/A:1013199507341

ROSA, M.F., SANTOS, F.J.S., MONTENEGRO, A.A.T., ABREU, F.A.P., CORREIA, D., ARAUJO, F.B.S. \& NORÕES, E.R.V. 2001. Caracterização do pó da casca de coco verde usado como substrato agrícola. Comunicado Técnico Embrapa Agroindústria Tropical, 54: 1-6

SANCHEZ, A.L. 2012. Análise de risco ecológico para o diagnóstico de impactos ambientais em ecossistemas aquáticos continentais tropicais. MsC Dissertation. Universidade de São Paulo. 216p.

SLOOTWEG, T., ALVINERIE, M., EGELER, P., GILBERG, D., KUKKONEN, J.V.K., OEHLMANN, J., PRASSE, C., SORMUNEN, A.J. \& LIEBIG, M. 2010. Bioaccumulation of ivermectin from natural and artificial sediments in the benthic organism Lumbriculus variegatus. J. Soils Sed., 10: 1611-1622. http://dx.doi.org/10.1007/s11368-010-0294-3

WAVRE, H. \& BRINKHURST, R.O. 1971. Interactions between some tubificid oligochaete and bacteria found in the sediments of Toronto Harbour, Ontario. J. Fish. Res. Board Can., 28: 335341. http://dx.doi.org/10.1139/f71-045. 